\title{
Green coffee seed residue: A sustainable source of antioxidant compounds
}

\author{
A.C.C.M. Castro ${ }^{\text {, F.B. Oda }}{ }^{\mathrm{a}}$, M.G.J. Almeida-Cincotto ${ }^{\mathrm{b}}$, M.G. Davanço ${ }^{\mathrm{a}}$, B.G. Chiari-Andréo, ${ }^{\mathrm{b}, \mathrm{c}}$, \\ R.M.B. Cicarelli ${ }^{\mathrm{d}}$, R.G. Peccinini ${ }^{\mathrm{a}}$, G.J. Zocolo ${ }^{\mathrm{e}}$, P.R.V. Ribeiro ${ }^{\mathrm{e}}$, M.A. Corrêa ${ }^{\mathrm{b}}$, V.L.B. Isaac ${ }^{\mathrm{b}}$,
} A.G. Santos ${ }^{a, *}$

a São Paulo State University (Unesp), School of Pharmaceutical Sciences, Araraquara, Department of Natural Principles and Toxicology, Rodovia Araraquara-Jaú, Km 01, 14800-903 Araraquara, São Paulo, Brazil

b São Paulo State University (Unesp), School of Pharmaceutical Sciences, Araraquara, Department of Drugs and Medicines, Rodovia Araraquara-Jaú, Km 01, 14800-903 Araraquara, São Paulo, Brazil

${ }^{\mathrm{c}}$ Biological and Health Sciences Department, Universidade de Araraquara - UNIARA, Rua Carlos Gomes, 1338, 14801-340 Araraquara, São Paulo, Brazil

d São Paulo State University (Unesp), School of Pharmaceutical Sciences, Araraquara, Department of Biological Sciences, Rodovia Araraquara-Jaú, Km 01, 14800-903 Araraquara, São Paulo, Brazil

e Embrapa Agroindústria Tropical, Empresa Brasileira de Pesquisa Agropecuária (Embrapa), Rua Dr. Sara Mesquita No. 2270, 60511-110 Fortaleza, Ceará, Brazil

\section{A R T I C L E I N F O}

\section{Keywords:}

Coffea arabica

Green seed residue

Agroindustrial residue

Antioxidant

Secondary metabolites

\begin{abstract}
A B S T R A C T
Oil extraction from green coffee seeds generates residual mass that is discarded by agribusiness and has not been previously studied. Bioactive secondary metabolites in coffee include antioxidant phenolic compounds, such as chlorogenic acids. Coffee seeds also contain caffeine, a pharmaceutically important methylxanthine. Here, we report the chemical profile, antioxidant activity, and cytotoxicity of hydroethanolic extracts of green Coffea arabica L. seed residue. The extracts of the green seeds and the residue have similar chemical profiles, containing the phenolic compounds chlorogenic acid and caffeine. Five monoacyl and three diacyl esters of trans-cinnamic acids and quinic acid were identified by ultra-performance liquid chromatography/electrospray ionizationquadruple time of flight mass spectrometry. The residue extract showed antioxidant potential in DPPH, ABTS, and pyranine assays and low cytotoxicity. Thus, coffee oil residue has great potential for use as a raw material in dietary supplements, cosmetic and pharmaceutical products, or as a source of bioactive compounds.
\end{abstract}

\section{Introduction}

Globally, coffee is a prominent commodity. Coffee trees belong to the Rubiaceae family, and Coffea arabica L. (arabica coffee) yields the best quality beverage (Abrahão, Pereira, Lima, Ferreira, \& Malta, 2008; Monteiro \& Trugo, 2005). Many studies concerning coffee have been published because of its economic and cultural importance, as well as its beneficial biological properties. Among the bioactive compounds present in coffee seeds, phenolic compounds stand out because of their antioxidant action. Of these phenolic compounds, chlorogenic acids are the main class responsible for the antioxidant activity. These compounds have in vitro free radical scavenging properties and prevents the propagation of oxidative processes (Ohnishi et al., 1994; Rivelli et al., 2007).

Chlorogenic acids are generated from the esterification of quinic acid with one or more trans-cinnamic acid derivatives. These compounds may be classified based on the type, number, and position of the acyl residues. The most common chlorogenic acids in coffee are monoesters of caffeoylquinic acid, especially 5-caffeoylquinic acid (5CQA) (Parras, Martínez-Tomé, Jiménez, \& Murcia, 2007). In addition to phenolic compounds, other secondary metabolites present in coffee are diterpenes (e.g., kahweol and cafestol), triterpenes, methylxanthines

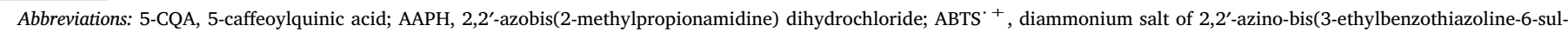

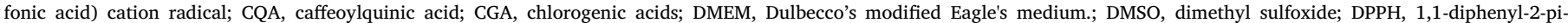

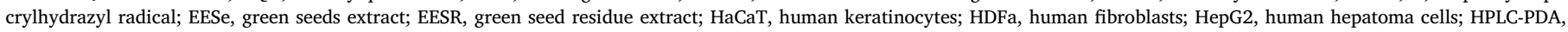

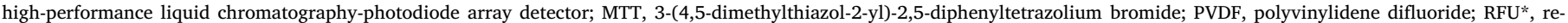

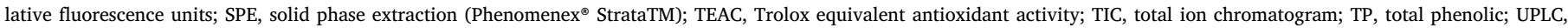
ultra-performance liquid chromatography; UPLC-ESI-QTOF-MSE, ultra-performance liquid chromatography/electrospray ionization-quadruple time of flight mass spectrometry

* Corresponding author.

E-mail addresses: carol_bhc@yahoo.com.br (A.C.C.M. Castro), fer_oda@msn.com (F.B. Oda), gabi.quimica@gmail.com (M.G.J. Almeida-Cincotto),

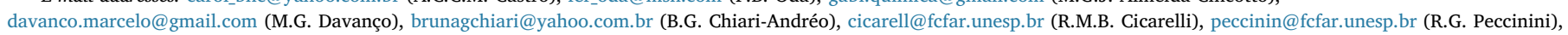
guilherme.zocolo@embrapa.br (G.J. Zocolo), paulo.riceli@embrapa.br (P.R.V. Ribeiro), correama@fcfar.unesp.br (M.A. Corrêa), veraisaac@gmail.com (V.L.B. Isaac), santosag@fcfar.unesp.br (A.G. Santos).
} 
(caffeine, theobromine, and theophylline), and trigonelline (Monteiro and Trugo, 2005; Parras et al., 2007). In addition to the well-known stimulant properties of caffeine, studies have also indicated its antioxidant potential through the in vitro inhibition of lipid peroxidation induced by free radicals (Parras et al., 2007).

In addition to the secondary metabolites in coffee, the cosmetic industry has interest in green coffee oil, which consists mainly of triglycerides and free fatty acids. This oil has cosmetic properties, including skin moisture retention and potential action in preventing photoaging (Velazquez Pereda Mdel et al., 2009). The green coffee seed oil content is about $15 \%(\mathrm{v} / \mathrm{w})$ of $C$. arabica, and the oil is produced by pressing the green seeds (Speer and Kölling-Speer, 2001). The obtained residue is a chemically rich material that is usually neglected by the coffee industry, and there is no information in the scientific literature concerning its chemical composition and biological properties.

Thus, we aimed to determine the qualitative and quantitative chemical composition, the antioxidant activity, and the cytotoxicity of a hydroethanolic extract of the residue from the oil extraction of green $C$. arabica seeds. For comparison purposes, the chemical composition and antioxidant activity of the hydroethanolic extract of green seeds before oil extraction were also assessed.

This extract may be further employed in dietary supplements, cosmetics, or pharmaceutical formulations as an antioxidant agent or as a source of important coffee secondary metabolites, such as caffeine and chlorogenic acids. This research also has importance from an environmental point of view and can meet the principles of green chemistry through the reuse of by-products generated by industry, minimizing their disposal in the environment (Farias and Fávaro, 2011; Prado, 2003).

\section{Material and methods}

\subsection{Plant material}

Green seed residue and green seeds of $C$. arabica were obtained from the coffee cooperative Cooxupé (Guaxupé, Minas Gerais, Brazil). Green seed residue $(300 \mathrm{~g})$ and green coffee seeds $(250 \mathrm{~g})$ were dried in an air circulation oven for $24 \mathrm{~h}$ at $40{ }^{\circ} \mathrm{C}$ and powdered in a knife mill.

\subsection{Granulometric analysis}

The granulometric analysis was carried out by sieving (Brasil, 2010). An aliquot (300.0 g) of dried green seed residue was placed in the first sieve of a set of six Tyler $^{\circledR}$ sieves $(600,250,180,125,75$, and $63 \mathrm{~mm}$ aperture) and shaken by a vibrating apparatus (Produtest ${ }^{\circledR}$ ) for $15 \mathrm{~min}$. At the end of the process, the powder retained in each sieve (\%, $\mathrm{w} / \mathrm{w}$ ) was weighed to determine the type of powder (Brasil, 2010) and also to calculate the average particle size (APS) using Eq. (1) (Aulton, 2005).

APS $=\sum$ (percentage retention $\times$ mean mesh aperture $) / 100$

The mean aperture of the meshes corresponds to the simple arithmetic mean of the aperture of the sieve through which the particles passed and the aperture of the sieve in which they were retained.

\subsection{Determination of water in the dried and powdered plant material}

The determination of water in the dried and powdered plant samples $(2.0 \mathrm{~g})$ was achieved by measuring the weight loss after drying in the air circulation oven $\left(110^{\circ} \mathrm{C}\right)$ to a constant weight (Brasil, 2010). The result is expressed as the ratio between the initial and final mass of plant material $(\% \mathrm{w} / \mathrm{w})$, based on the mean of three determinations.

\subsection{Selection of solvent mixture for extraction}

Aliquots of green seed residue $(1.0 \mathrm{~g})$ were sonicated with four different hydroalcoholic mixtures: 70 and $80 \%$ ethanol and 60 and $80 \%$ methanol, separately. Each extraction occurred in three steps using $5 \mathrm{~mL}$ of solvent for $20 \mathrm{~min}$ per step, and the total solvent/sample ratio was $15 \mathrm{~mL} / \mathrm{g}$. The extractive solutions of each solvent mixtures were pooled, filtered, and dried in a SpeedVac (Thermo Scientific ${ }^{\circledR}$ SPD131DDA). The total phenolic content (Section 2.6) and the antioxidant activity (Section 2.10) of these extracts were determined by the selection of the most suitable solvent mixture for large-scale extraction.

\subsection{Preparation of large-scale extraction}

The green seed residue $(300 \mathrm{~g})$ and green seeds ( $250 \mathrm{~g}$ ) were extracted by maceration with $70 \%$ ethanol $\left(40{ }^{\circ} \mathrm{C}\right)$. The extraction was realized in three 24,48 , and 48 -h long steps, using $1500 \mathrm{~mL}$ of $70 \%$ ethanol in each step for green seed residue and $1250 \mathrm{~mL}$ in each step for green seeds. The extractive solutions were pooled, filtered, concentrated under reduced pressure for ethanol elimination, and then lyophilized, yielding dry extracts from the green seed residue of $C$. arabica (EESR) and green seeds of $C$. arabica (EESe).

\subsection{Determination of the total phenolic content}

The total phenolic (TP) content of the dried extracts was determined by a method previously described by Singleton, Orthofer, \& LamuelaRaventós, 1999 using the Folin-Ciocalteu reagent and analytical curves determined from gallic acid $(1.25-20 \mu \mathrm{g} / \mathrm{mL})$ for the selection of a suitable solvent mixture for extraction (Section 2.3) and 5-CQA $(2-30 \mu \mathrm{g} / \mathrm{mL})$ for the determination in large-scale extractions (Section 2.4). All extracts were solubilized in deionized water at a concentration of $30 \mu \mathrm{g} / \mathrm{mL}$. Experiments were performed in triplicate. The results are expressed in micrograms of total phenolic compound equivalents to 5CQA or gallic acid per $100 \mu \mathrm{g}$ of extract.

\subsection{Sample pretreatment for ultra-performance liquid chromatography (UPLC) analysis}

EESR and EESe $(15 \mathrm{mg})$ were dissolved in 1.0-mL of a methanol:water solution $(90: 10, \mathrm{v} / \mathrm{v})$ and submitted to solid phase extraction (SPE, Phenomenex ${ }^{\circledR}$ Strata $^{\mathrm{TM}}$ C18-E; $15 \times 10 \mathrm{~mm}$; $55 \mu \mathrm{m}$ ). The $\mathrm{C} 18$ cartridge was activated with methanol $(10 \mathrm{~mL})$ and conditioned with methanol:water $(90: 10, \mathrm{v} / \mathrm{v})$. Following the application of the samples, the cartridges were eluted with $4.0 \mathrm{~mL}$ of methanol:water $(90: 10, \mathrm{v} / \mathrm{v})$. Eluates from the EESR and EESe were dried, dissolved in methanol $(1.0 \mathrm{~mL})$, and filtered through polyvinylidene difluoride (PVDF) membranes $\left(0.22 \mu \mathrm{m}\right.$, Millipore $\left.{ }^{\circledR}\right)$ before UPLC analysis.

\subsection{UPLC-UV analysis}

Chromatographic analysis was performed on an UPLC system (Waters Acquity UPLC ${ }^{\circledR}$ ) equipped with UV-Vis detector 2487. The chromatographic conditions were an high-strength silica (HSS) C18 SB Waters ${ }^{\circledast}$ column $(2.1 \times 100 \mathrm{~mm} ; 1.8 \mu \mathrm{m})$ with a mobile phase of $2 \%(\mathrm{v} /$ v) acetic acid in water (eluent $\mathrm{A}$ ) and $0.5 \%$ acetic acid in water and acetonitrile (50:50, v/v, eluent $B$ ); the gradient elution conditions were as follows: $10-12 \% \mathrm{~B}(1.5 \mathrm{~min}), 12 \% \mathrm{~B}(1.5-3.5 \mathrm{~min}), 12-40 \% \mathrm{~B}$ (3.5-4.5 min), 40\% B (4.5-7.5 min), 40-100\% B (7.5-8.5 min), $100-10 \% \quad$ B $\quad(8.5-9.5 \mathrm{~min}), \quad 10 \% \quad \mathrm{~B} \quad(9.5-11.5 \mathrm{~min})$, flow rate $0.55 \mathrm{~mL} \mathrm{~min}^{-1}$, and injection volume $1 \mu \mathrm{L}$. The column oven was operated at $30^{\circ} \mathrm{C}$. Caffeic acid, 5-CQA, rutin, quercetin, and caffeine chromatographic standard (Sigma-Aldrich ${ }^{\circledR}$ ) solutions (methanol; $1.0 \mathrm{mg} / \mathrm{mL}$ ) were used for identification purposes. Analytical curves for caffeine (methanol; $0.25-2.0 \mathrm{mg} / \mathrm{mL}$ ) and 5-CQA (methanol; $0.25-10.0 \mathrm{mg} / \mathrm{mL}$ ) were obtained for quantification by an external 
standardization method.

2.9. Ultra-performance liquid chromatography/electrospray ionizationquadruple time of flight mass spectrometry (UPLC-ESI-QToF-MS ${ }^{E}$ ) analysis of EESR

The analysis was performed on an Acquity UPLC system (Waters ${ }^{\circledR}$ ) coupled to a quadrupole/time of flight (Xevo-QTOF, Waters ${ }^{\circledast}$ ) system. The chromatographic conditions were the same as those used for UPLCUV analysis with the following modifications: a BEH C18 Waters ${ }^{\circledR}$ column $(2.1 \times 150 \mathrm{~mm} ; 1.7 \mu \mathrm{m})$ was used with a flow rate of $0.4 \mathrm{~mL} \mathrm{~min}^{-1}$, the column oven was set to $40^{\circ} \mathrm{C}$, and the injection volume was $5 \mu \mathrm{L}$. $\mathrm{ESI}^{-}$mode was acquired in the range of $110-1180 \mathrm{Da}$, the source temperature was fixed at $120^{\circ} \mathrm{C}$, the desolvation gas temperature was $350^{\circ} \mathrm{C}$, the desolvation gas flow was $500 \mathrm{~L} / \mathrm{h}$, the extraction cone voltage was $0.5 \mathrm{~V}$, and the capillary voltage was $2.6 \mathrm{kV}$. In low scan mode, the cone voltage was $35 \mathrm{~V}$ with a collision energy of $5 \mathrm{eV}$ (trap). In high scan mode, the cone voltage was $35 \mathrm{~V}$ with a collision energy ramp of $20-40 \mathrm{eV}$ (trap). Leucine encephalin was used as the lock mass. The acquisition mode was $\mathrm{MS}^{\mathrm{E}}$. The equipment was controlled by Masslynx 4.1 (Waters ${ }^{\circledR}$ Corporation) software.

\subsection{DPPH radical scavenging assay}

The 1,1-diphenyl-2-picrylhydrazyl radical (DPPH') scavenging activity was determined using the method proposed by Mensor et al. (2001) with the following modifications. For the radical scavenging evaluation for the selection of a solvent for extraction (Section 2.3), $60 \%$ and $80 \%$ methanol and $70 \%$ and $80 \%$ ethanol dry extracts were solubilized in water $(7.0 \mu \mathrm{g} / \mathrm{mL})$, and $1.0 \mathrm{~mL}$ of each aqueous solution was added to $2.5 \mathrm{ml}$ of a methanolic DPPH solution $(0.004 \%$, w/v). For the radical scavenging evaluation of EESR and EESe (Section 2.4), $1.0 \mathrm{~mL}$ of an aqueous solution of EESR $(0-25 \mu \mathrm{g} / \mathrm{mL})$ and EESe $(0-30 \mu \mathrm{g} / \mathrm{mL}$ for EESE) were added to $2.5 \mathrm{~mL}$ of a methanolic DPPH solution $(0.004 \%$; w/v). Ascorbic acid $(0.5-5.0 \mathrm{mg} / \mathrm{mL}$; aqueous solution) was used as the standard. Assays were performed in triplicate, and the percentage inhibition of $\mathrm{DPPH}^{-}$was calculated. From the values of the percentage inhibition of DPPH ${ }^{*}$, the inhibition curves and the $\mathrm{IC}_{50}$ values were obtained.

\subsection{ABTS radical scavenging assay}

The 2,2'-azino-bis(3-ethylbenzothiazoline-6-sulfonic acid) cation radical (ABTS ${ }^{++}$) assay was performed as described by Rufino et al. (2007) with the following modification. After the formation of ABTS ${ }^{*}$ from the methanolic solution of the diammonium salt of 2,2'-azino-bis (3-ethylbenzothiazoline-6-sulfonic acid), $2 \mathrm{~mL}$ of the ABTS $^{-+}$solution was added to $1030 \mu \mathrm{L}$ of the EESR and EESe aqueous solutions at different concentrations $(1.55-27.18 \mu \mathrm{L} / \mathrm{mL})$. The percentage inhibition of $\mathrm{ABTS}^{+}$was determined as described in the DPPH radical scavenging assay. Ascorbic acid $(0.48-3.49 \mu \mathrm{L} / \mathrm{mL}$; aqueous solution) was used as the standard. Assays were performed in triplicate.

\subsection{Suppressive effect of peroxyl radical (AAPH/pyranine) assay}

This test was conducted following the method proposed by Campos, Sotomayor, Pino, and Lissi (2004). A 2,2'-azobis(2-methylpropionamidine) dihydrochloride (AAPH) solution $(125 \mu \mathrm{L} ; 20 \mathrm{mM})$ was added to $100 \mu \mathrm{L}$ of pyranine $(0.005 \mu \mathrm{g} / \mathrm{mL})$ in a dark 96 -well plate. The EESR solutions $(25 \mu \mathrm{L})$ were added to the plates at different concentrations $(5-20 \mu \mathrm{g} / \mathrm{mL})$. Trolox was used as the antioxidant reference compound $(0.005-0.02 \mu \mathrm{g} / \mathrm{mL})$, and a negative control was prepared without EESR or Trolox, as described above. All solutions were prepared in phosphate buffered saline (PBS). The final volume of reaction plate was $250 \mu \mathrm{L}$. Pyranine bleaching was monitored using an excitation wavelength of $460 \mathrm{~nm}$ and an emission wavelength of $510 \mathrm{~nm}$ in a Spectramax M2 microplate reader (Molecular Devices ${ }^{\circledast}$, USA) at $37^{\circ} \mathrm{C}$. The results were expressed as Trolox equivalent antioxidant activity (TEAC). Assays were performed in triplicate.

\subsection{MTT cytotoxicity assay}

The cytotoxic potential of EESR was evaluated by the 3-(4,5-dimethylthiazol-2-yl)-2,5-diphenyltetrazolium bromide (MTT) assay (Chiari et al., 2012; Mosmann, 1983) against three cell lines (human keratinocytes (HaCaT), human fibroblasts (HDFa), and human hepatoma cells (HepG2)). Cells were grown in culture flasks containing Dulbecco's modified Eagle's medium (DMEM) supplemented with $10 \%$ fetal calf serum and antibiotics (penicillin, $100 \mathrm{U} / \mathrm{mL}$; streptomycin, $0.1 \mathrm{mg} / \mathrm{mL}$ ). The cultures were incubated at $37 \pm 2{ }^{\circ} \mathrm{C}$ in an atmosphere of $5 \% \mathrm{CO}_{2}$. Cells were transferred into 96-well plates with a cell density of $1.0 \times 10^{6}$ cells $/ \mathrm{mL}$. Plates were incubated for $24 \mathrm{~h}$ for complete cell adhesion to the plates. The treatments (for $24 \mathrm{~h}$ ) involved a $100-\mu \mathrm{L}$ positive control ( $10 \%$ dimethyl sulfoxide (DMSO)), a negative control (DMEM without serum), and different concentrations of EESR $(0-11,000 \mu \mathrm{g} / \mathrm{mL}$ solubilized in DMEM without serum). Then, the treatments were removed, the plates were washed with PBS and $100 \mu \mathrm{L}$ of MTT in PBS $(1.0 \mathrm{mg} / \mathrm{mL})$ was added to each well, followed by incubation for $3-5 \mathrm{~h}$. After that, the supernatant was removed, and formazan crystals were solubilized in $100 \mu \mathrm{L}$ of isopropyl alcohol. The percentage of non-viable cells was calculated in relation to the absorbance of the negative control $(595 \mathrm{~nm})$, as proposed by Zhang, Wu, Tashiro, Onodera, \& Ikejima (2004). Thus, the viability was obtained using the following formula: percentage of non-viable cells $=\left[\left(\mathrm{A}_{\text {negative }}\right.\right.$ control $\left.\left.-A_{\text {treatment }}\right) / A_{\text {negative control }}\right] \times 100$. For the determination of viable cells, this percentage was deducted from $100 \%$. For different cell lines, the $\mathrm{IC}_{50}$ was calculated by linear regression of the obtained curves. Cytotoxicity assays were performed in at least three independent assays, and each assay treatment was realized in triplicate.

\subsection{Statistical analysis}

Analyzes were carried out using the InStat3 software (GraphPad ${ }^{\circledR}$, San Diego, CA, USA). The results are presented as the mean and the standard deviation (SD). Statistical analyses of the data were performed using the one-way analysis of variance (ANOVA) and Tukey's post-test assuming significance for $p<.001, p<.01$, and $p<.05$.

\section{Results and discussion}

\subsection{Selection of the solvent mixture for extraction and large-scale extractions}

The efficiency and selectivity of the extraction of phenolic compounds from plant materials vary with many factors, such as their chemical structures, extraction technique, possible interfering compounds, and particle size (Naczk \& Shahidi, 2004). Thus, green seed residue of $C$. arabica was characterized and classified according to the Brazilian Pharmacopeia as a fine powder (all the particles passed through a through the sieve with a nominal mesh aperture of $180 \mathrm{~mm}$ ) and its calculated average particle size was $122.1 \mu \mathrm{m}$ (Aulton, 2005).

Furthermore, the solubility of these compounds is related to the degree of polymerization and their interactions with other plant components and, especially, the type of solvent used for extraction (Naczk \& Shahidi, 2004). The most efficient solvents for phenolic compounds extraction are methanol, ethanol, water, or hydroalcoholic mixtures (Shouqin, Jun, \& Changzheng, 2005). In this study, 60 and $80 \%$ methanol and 70 and $80 \%$ ethanol were tested as solvent mixtures for extraction using sonication. The yield, content of total phenolic compounds, and antioxidant activity (DPPH method) of the extracts are shown in Table 1. The total phenolic content of the extract (Table 1) 
Table 1

Data on selection of extractor solvent mixture: extraction yield, content of total phenolic compounds (TP) equivalents to gallic acid in dry extracts and their antioxidant activities measured by DPPH radical method.

\begin{tabular}{llll}
\hline Extract & $\begin{array}{l}\text { Extraction yield } \\
(\%)^{\mathrm{a}}\end{array}$ & $\begin{array}{l}\text { TP content in dry } \\
\text { extract }(\%)^{\mathrm{b}}\end{array}$ & $\begin{array}{l}\text { DPPH inhibition } \\
(\%)\end{array}$ \\
\hline $60 \%$ methanol & 28.0 & $11.5 \pm 0.007^{\mathrm{c}}$ & $22.5 \pm 5.3^{\mathrm{e}}$ \\
$80 \%$ methanol & 26.7 & $13.8 \pm 0006^{\mathrm{d}}$ & $18.8 \pm 5.9^{\mathrm{f}}$ \\
$70 \%$ ethanol & 24.8 & $14.7 \pm 0007^{\mathrm{d}}$ & $22.5 \pm 6.9^{\mathrm{e}}$ \\
$80 \%$ ethanol & 24.2 & $11.7 \pm 0002^{\mathrm{c}}$ & $18.7 \pm 3.7^{\mathrm{f}}$ \\
\hline
\end{tabular}

c,d,e,f different superscripts in the same column indicate statistical differences $(\mathrm{p}<.05)$.

a (extract weight/seed residue weight) $\times 100$.

${ }^{\mathrm{b}}$ percentage of total phenolic compounds equivalents to gallic acid in dry extracts.

was calculated using the analytical curve of gallic acid.

Considering the minimal confidence level $(p<.05)$, Table 1 shows that $70 \%$ ethanol and $60 \%$ methanol green seed residue extracts showed higher values of $\mathrm{DPPH}^{-}$inhibition $(22.5 \%)$ compared to $80 \%$ methanol and $80 \%$ ethanol ( $18.8 \%$ and $18.7 \%$, respectively). Furthermore, $70 \%$ ethanol and $80 \%$ methanol green seed residue extracts had higher total phenolic contents (14.7\% and $13.8 \%$, respectively) compared to the other extracts. Because the yield of extracts was similar and based on the above results and green chemistry principles, such as toxicity and sustainability (Farias and Fávaro, 2011; Prado, 2003), 70\% ethanol was chosen for the proposed extraction.

The yields of the large-scale extraction by maceration with $70 \%$ ethanol of green $C$. arabica seed residue (EESR) and green seeds (EESe) were 21 and $20.4 \%(\mathrm{w} / \mathrm{w})$, respectively, considering the water content of the dried plant material ( $8.8 \%$ and $4.4 \%(\mathrm{w} / \mathrm{w})$, respectively).

\subsection{Chemical analysis of EESR and EESe}

The determination of the total phenolic content of the EESR and EESe (Table 2) using the Folin-Ciocalteu method was realized using the analytical curve of 5-CQA. Regarding the chemical analysis of the phenolic compounds, the Folin-Ciocalteu assay does not give a detailed profile of the phenolic compounds present in the samples and is based on the determination of the reducing capacity of a sample. On the other hand, as a preliminary test, it suggests that the extracts under study have a significant phenolic content and potential antioxidant activity, as demonstrated below by the DPPH, ABTS, and pyranine assays (Section 3.3).

The total phenolic content determined in the EESR $(27.9 \%, \mathrm{w} / \mathrm{w})$ was statistically $(p<.05)$ the same as that of the EESe $(27.4 \%, \mathrm{w} / \mathrm{w})$ (Table 2) and may be considered high when compared to other coffee by-products and food matrices. Concerning the phenolic contents of other coffee by-products, Murthy and Naidu (2012) found that the $60 \%$ isopropanol extract from the silver skin, spent waste, and the cherry husk of coffee industry contained $25 \%, 19 \%$, and $17 \%(\mathrm{w} / \mathrm{w})$ of phenolic compounds, respectively. However, Sant'Anna et al. (2017) found a content of $0.6 \%$ in the aqueous extract from dark roasted spent ground coffee, whereas Zuorro \& Lavecchia (2012) found values of $1.8 \%$ and $2.2 \%$ (dry matter) for $50 \%$ ethanol extract of spent coffee

Table 2

Quantitative chemical analysis of EESR and EESe.

\begin{tabular}{lll}
\hline Compounds & EESR (\% w/w) & EESe (\% w/w) \\
\hline $\begin{array}{ll}\text { total phenolic compounds (5-CQA } \\
\quad \text { equivalents) }\end{array}$ & $27.9 \pm 0.006^{\mathrm{a}}$ & $27.4 \pm 0.005^{\mathrm{a}}$ \\
$\begin{array}{l}\text { 5-CQA } \\
\text { caffeine }\end{array}$ & $21.7 \pm 0.72^{\mathrm{d}}$ & $13.2 \pm 0.35^{\mathrm{e}}$ \\
& $7.2 \pm 0.22^{\mathrm{f}}$ & $5.9 \pm 0.19^{\mathrm{g}}$ \\
\hline
\end{tabular}

EESe - C. arabica green seeds extract. EESR - C. arabica green seed residue extract. 5-CQA - 5-caffeoylquinic acid.

a,b,c,d,e,f,g different superscripts in the same line indicate statistical differences $(\mathrm{p}<.05)$. grounds collected from coffee bars and capsules, respectively. Regarding other food matrices Peschel et al. (2006) analyzed ethanol extracts of residues from apple, pear, strawberry, and red beet juice production and obtained values ranging from $4.2 \%$ to $12.2 \%$. Sousa et al. (2014) determined the total phenolic compounds content as $23 \%$ $(\mathrm{w} / \mathrm{w})$ in a $65 \%$ ethanol extract of the bark of Stryphnodendron adstringens (Mart.) Coville. All these studies employed the Folin-Ciocalteu method and results are expressed as gallic acid equivalents.

Schieber, Keller, and Carle (2001) developed a method using a highperformance liquid chromatography-photodiode array detector (HPLCPDA), which was employed for the development of a method by UPLCUV for the identification and the quantification of secondary metabolites in EESR and EESe to reduce the time for the chromatographic analysis and the consumption of solvents. The HPLC conditions reported by Schieber et al. (2001) were transferred to UPLC conditions using the Acquity ${ }^{\circledR}$ UPLC Column Calculator software, and the mobile phase composition was experimentally optimized.

Fig. 1 shows chromatograms for EESR using the UPLC-UV selected conditions. Both extracts (EESR and EESe) presented similar chromatographic profiles. 5-CQA and caffeine were identified based on a comparison of the retention time $\left(t_{\mathrm{R}}\right)$ and the co-injection of standards added to the extracts. On the other hand, caffeic acid, rutin, and quercetin were not identified in the extracts through comparison of $t_{R}$.

The analytical curves of 5-CQA and caffeine were obtained for quantification purposes. The higher values of these compounds in EESR $(21.7 \pm 0.72$ and $7.2 \pm 0.22$, respectively) than in EESe (13.2 \pm 0.35 and $5.9 \pm 0.19$, respectively), as shown in Table 2, may be related to the components extracted from the green seeds, especially the fixed oil, that are not present in the green seed residue. In addition, these contents are higher than those described in the literature for the aqueous extract of the green seeds of $C$. arabica, which range from $9.7 \%$ to $12.2 \%$ of 5 -CQA and $3.4 \%$ to $3.8 \%$ of caffeine (Jeszka-Skowron, Sentkowska, Pyrzyńska, \& De Pena, 2016), 60\% isopropanol extract of other coffee by-products, which contained $10.8 \%$ to $15.8 \%$ of 5 -CQA (Murthy \& Naidu, 2012), and aqueous extract of coffee silverskin containing $0.4 \%$ to $2.6 \%$ of caffeine content (Narita \& Inouye, 2012).

The total ion chromatogram (TIC) of EESR determined using UPLCESI-QTOF-MS ${ }^{\mathrm{E}}$ in negative ion mode showed several peaks with good resolution. The identified compounds (Table 3) include five monoacyl (2-6) and three diacyl (10-12) esters of trans-cinnamic acids and quinic acid, the so-called chlorogenic acids (CGA), which have been previously reported to be present in C. arabica (Clifford, Johnston, Knight, \& Kuhnert, 2003). The putative identification of these compounds is based on the accurate mass (empirical formula), mass fragmentation patterns, and scientific literature (Clifford, Knight, \& Kuhnert, 2005; Rodrigues et al., 2012; Vallverdu-Queralt, Jauregui, Medina-Remon, Andres-Lacueva, \& Lamuela-Raventos, 2010; Yuan et al., 2015). In addition, we employed the hierarchical key for identification of chlorogenic acids proposed by Clifford et al. (2005). The main peak of the TIC with a $t_{\mathrm{R}}$ of $5.02 \mathrm{~min}$ corresponds to 5-CQA, which was also the main compound in the UPLC-UV analysis.

Compounds 2-6 yield the parent ion [monoacyl CGA-H] ${ }^{-}$that identifies the CGA classes. Their $\mathrm{MS}^{2}$ spectra showed fragment ion signals at $m / z 191$ and 173, typical of the quinic acid moiety and $m / z$ 163,179 , and 193, which indicate the presence of $p$-coumaroyl, caffeoyl, or feruloyl moieties, respectively, in their chemical structures.

Compounds 2-4 showed molecular ion signals at $m / z 353.0875$, 353.0871 and $353.0876[\mathrm{M}-\mathrm{H}]^{-}$, respectively, that match the empirical formula $\mathrm{C}_{16} \mathrm{H}_{17} \mathrm{O}_{9}$ of caffeoylquinic acid (CQA). A MS ${ }^{2}$ fragment ion signal at $m / z 179$ relative to the caffeoyl moiety was observed for all compounds. According to the hierarchical key of Clifford et al. (2005), the isomers of CQA may be distinguished considering the intensities of the fragment ion signals at $m / z 191,179$, and 173 in the $\mathrm{MS}^{2}$ spectrum provided the fragmentation energy is not excessive.

The CQA substituted at positions 1,3 , and 5 of the quinic acid moiety has a base peak at $m / z 191$, as observed for compound 2 . Its 


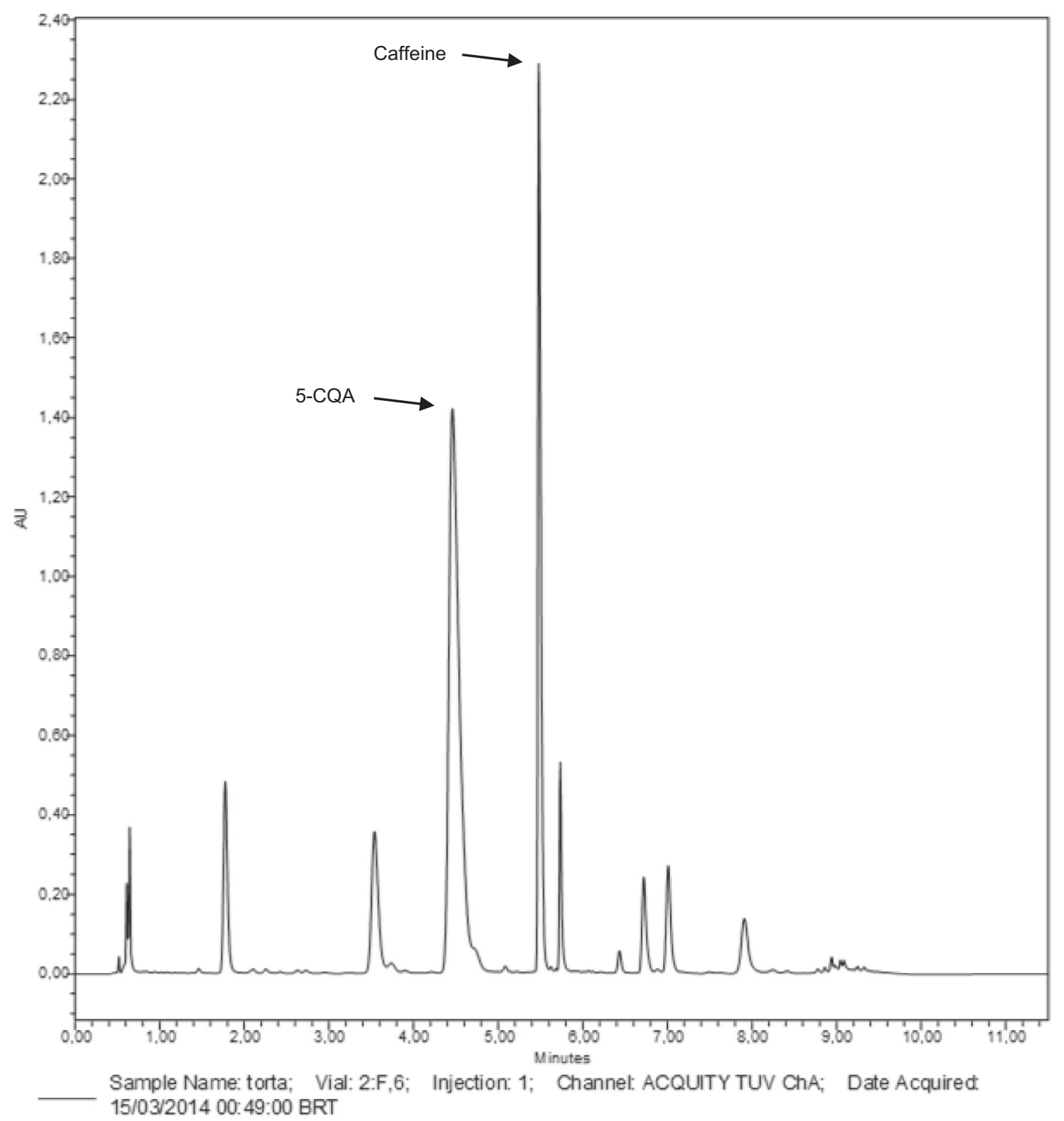

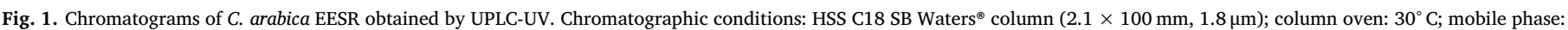

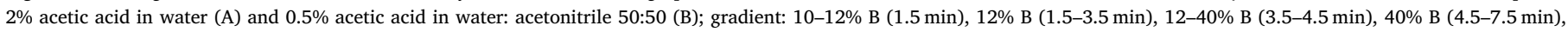

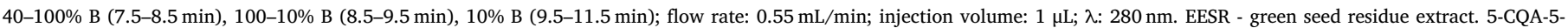
caffeoylquinic acid.

spectrum contains a fragment ion signal at $m / z 179$ with a relative intensity of less than $50 \%$, which is characteristic of 3-CQA. Thus, compound 2 was putatively identified as 3-CQA (neochlorogenic acid). The mass spectrum of compound 3 contained a base peak at $m / z 191$ and a fragment ion signal at $m / z 179$ with a relative intensity of $3 \%$, which is typical for 1-CQA or 5-CQA. A commercial chromatographic standard of 5-CQA was employed to confirm its identity through UPLCESI-QTOF-MS ${ }^{\mathrm{E}}$ analysis using $t_{\mathrm{R}}$ comparison and co-injection with EESR. Furthermore, C. arabica does not synthesize 1-acyl-quinic acids (Clifford et al., 2005). 4-Acyl CQA has a base peak at $m / z 173$ instead of 191. Compound 4 showed a fragment ion signal at $m / z 173$ with a relative intensity of $99 \%$ and was putatively identified as 4-CQA (cryptochlorogenic acid).

Compound 5 showed a molecular ion signal at $m / z 337.0919$ $[\mathrm{M}-\mathrm{H}]^{-}$that matches the empirical formula $\mathrm{C}_{16} \mathrm{H}_{17} \mathrm{O}_{8}$ of $p$-coumaroylquinic acid ( $p$ CoQA). The $\mathrm{MS}^{2}$ fragment ion signal at $m / z 163$ corresponds to the p-coumaroyl moiety. According to Clifford et al. (2003), it is possible to distinguish $p$ CoQA isomers considering the base peak in the $\mathrm{MS}^{2}$ spectrum. The spectrum of compound $\mathbf{5}$ contains a base peak at $m / z 191$ and was putatively identified as 5-pCoQA.

The spectrum of compound 6 contains a molecular ion signal at $m / z$ $367.1027[\mathrm{M}-\mathrm{H}]^{-}$that matches the empirical formula $\mathrm{C}_{17} \mathrm{H}_{19} \mathrm{O}_{9}$ of feruloylquinic acid (FQA). The $\mathrm{MS}^{2}$ fragment ion signal at $\mathrm{m} / \mathrm{z} 193$ corresponds to the feruloyl moiety. The base peak observed for compound 6 in the MS ${ }^{2}$ spectrum at $m / z 191$ is typical of an FQA isomer substituted at position 5 of the quinic acid moiety. Thus, compound 6 was putatively identified as 5-FQA.

Compounds 10-12 yield the parent ions [diacyl CGA-H] ${ }^{-}$at $m / z$ 515.1188, 515.1191, and 515.1194 $[\mathrm{M}-\mathrm{H}]^{-}$, respectively, which match with the empirical formula $\left(\mathrm{C}_{25} \mathrm{H}_{23} \mathrm{O}_{12}\right)$ of dicaffeoylquinic acid (diCQA). The $\mathrm{MS}^{2}$ fragment ion signal at $\mathrm{m} / z 179$ is relative to the caffeoyl moiety. The three diCQA produced subtle differences in 
fragmentation, but in the absence of $\mathrm{MS}^{3}$ spectra the hierarchical key of Clifford et al. (2005) could not be used. In our study, the first and last to elute yielded $\mathrm{MS}^{2}$ base peaks at $m / z 173$ whereas the second to elute yielded an $\mathrm{MS}^{2}$ base peak at $m / z 191$. These $\mathrm{MS}^{2}$ base peaks correspond to the $\mathrm{MS}^{3}$ base peaks reported by Clifford et al. (2003) and accordingly we assign them as 3,4-diCQA, 3,5-diCQA and 4,5-diCQA in order of elution.

The spectra of compounds $\mathbf{1 0}$ and $\mathbf{1 2}$ contain a fragment ion signal at $m / z 179$ with a relative intensity of less than $50 \%$, precluding the possibility of the identification of 1,4-diCQA. According to Clifford et al. (2005), 3,4-diCQA presents a fragment ion signal at $m / z 335$ $(\sim 15 \%)$ in the $\mathrm{MS}^{2}$ spectrum that is not detectable for 4,5-diCQA. This fragment ion signal was observed for compound $\mathbf{1 0}$ with a relative intensity of $17 \%$, and compound 10 was putatively identified as 3,4diCQA. Compound 12 did not show this fragment ion signal and, based on the hierarchical key for the identification of CGA, it was putatively identified as 4,5-diCQA. (Clifford et al., 2005).

Compound 11 contains a base peak at $m / z 191$ in its $\mathrm{MS}^{2}$ spectrum, as well as a fragment ion signal at $m / z 179$ with a relative intensity of $65 \%$, suggesting 1,5-diCQA or 3,5-diCQA. A comparison of the fragmentation patterns of compound $11\left(\mathrm{MS}^{2}\right), 1,5$-diCQA and 3,5-diCQA $\left(\mathrm{MS}^{3}\right.$ ) (Clifford et al., 2005) indicates similar fragmentation patterns between compound 11 and 3,5-diCQA. Moreover, in C. arabica, esterification does not occur at position 1 . Thus, compound 11 was putatively identified as 3,5-diCQA.

UPLC-ESI-QTOF-MS ${ }^{\mathrm{E}}$ and UPLC-UV chemical analysis of EESR show that the green coffee seeds and green coffee seed residue have similar qualitative chemical compositions. Quantitative analysis shows that EESR has a greater content of caffeine and 5-CQA than EESe considering the statistical significance $(p<.05)$. A comparison of the chemical composition of EESR and EESe indicates that the coffee seed residue may be an interesting source of CGAs and caffeine.

\subsection{Determination of the antioxidant activity of EESR and EESe}

The determination of the antioxidant activity of EESR and EESe was carried out using several methods, allowing better comprehension of the results. Each assay evaluates the antioxidant capacity under different experimental conditions and kinetics, and, thus, the results are complementary (Jeszka-Skowron, Stanisz, \& De Pena, 2016). Müller, Fröhlich, and Böhm (2011) found that the activities of the compounds with respect to the scavenging radicals depended strongly on the assay employed. The use of different methods to describe the antioxidant activity of plant derivatives has been extensively described in the literature (Dudonné, Vitrac, Coutière, Woillez, \& Mérillon, 2009; JeszkaSkowron, Stanisz, et al., 2016; Müller et al., 2011).

The DPPH method is based on measurement of the capacity of an antioxidant compound to scavenge the DPPH radical, reducing it to hydrazine. The $\mathrm{IC}_{50}$ values were calculated from data of the graph of percentage of inhibition of the DPPH radical versus ascorbic acid, EESR, or EESe concentrations $(\mu \mathrm{g} / \mathrm{mL})$. The $\mathrm{IC}_{50}$ values for ascorbic acid, EESR, and EESe are 3.3, 17.0, and $17.5 \mu \mathrm{g} / \mathrm{mL}$, respectively. The IC 50 values obtained for the extracts were very close and are statistically equal $(p<.05)$ and higher than the $\mathrm{IC}_{50}$ value for ascorbic acid.

Murthy and Naidu (2012) tested different by-products of coffee extracted with water:isopropanol mixtures and found antioxidant activities of $61 \%$ to $70 \%$ between 100 and $500 \mu \mathrm{g} / \mathrm{mL}$. In our work, we tested 16 times lower concentration of EESR $(25.0 \mu \mathrm{g} / \mathrm{mL})$ and found a DPPH scavenger activity of approximately 75\%. Jeszka-Skowron, Stanisz, et al. (2016) evaluated infusions of the green seeds of $C$. arabica from various countries. The infusions were diluted 1:100 (v/v, methanol) and the maximum DPPH scavenging activity obtained was 59.8\% using seeds from Peru. The Brazilian seeds assessed by these authors were able to scavenge $47.5 \%$ of the DPPH radicals. A comparison with our results is not easy due to the differences in the manner of extraction, dilution, and concentrations; however, using the EESR 
(a)

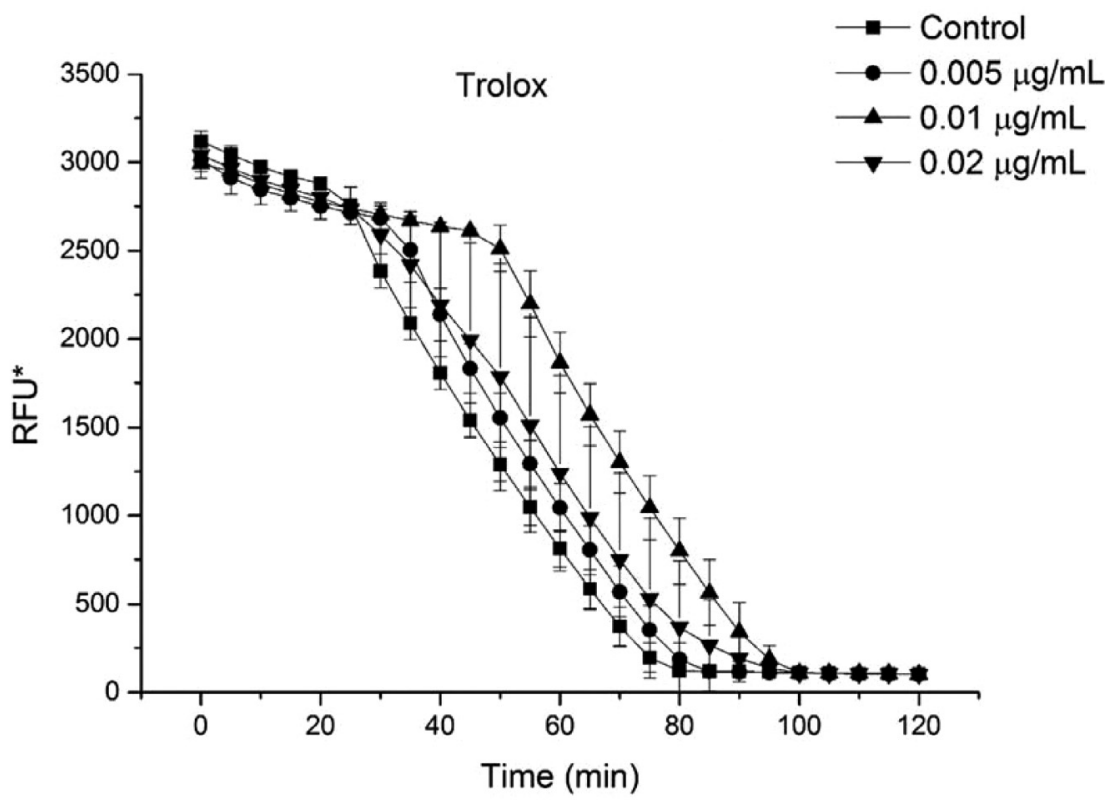

Fig. 2. Graph kinetic profile of fluorescence decay pyranine with Trolox (a) and C. arabica EESR (b). RFU* (Relative fluorescence units). EESR - green seed residue extract.

(b)

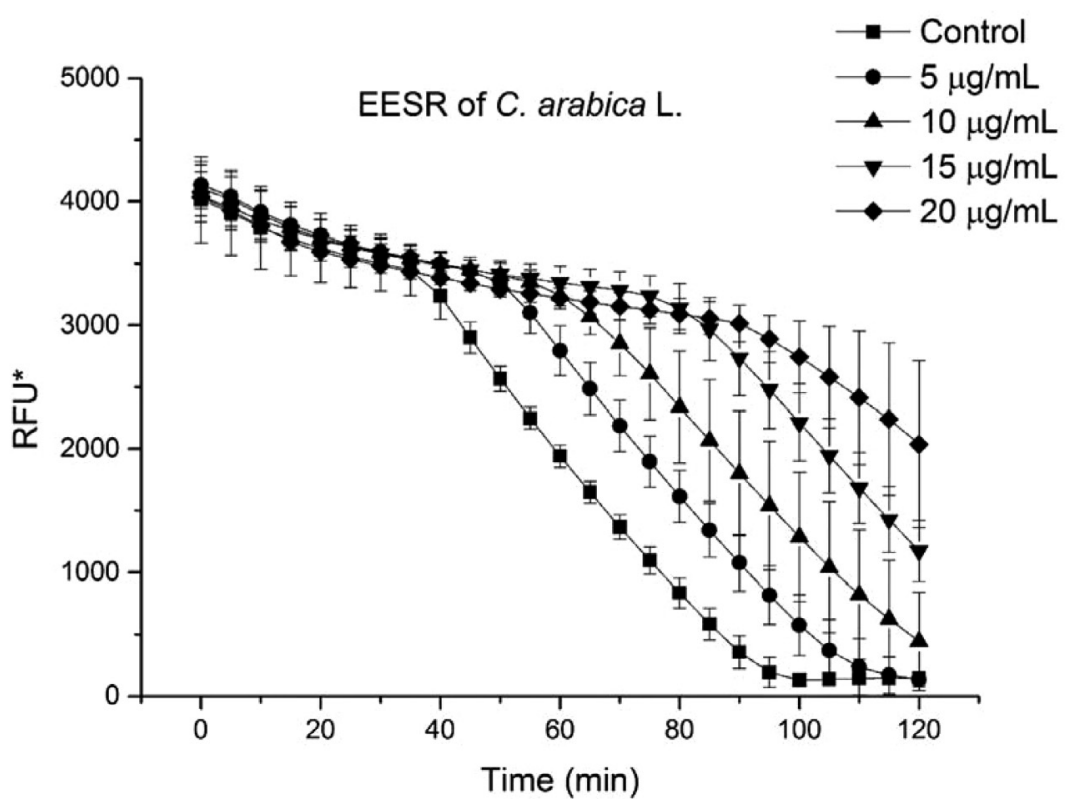

and EESe in the maximum concentrations assessed (25.0 and $30.0 \mu \mathrm{g} /$ $\mathrm{mL}$, respectively), the DPPH scavenger activities were $75 \%$ and $90 \%$, respectively.

Okonogi, Duangrat, Anuchpreeda, Tachakittirungrod, \& Chowwanapoonpohn (2007) compared the antioxidant capacity of the most commonly consumed fruit peels in Thailand using radicalscavenging activity of DPPH. The best results of the antioxidant capacity were for an extract of pomegranate peel (Punica granatum L.) with an $\mathrm{IC}_{50}$ of $3.0 \mu \mathrm{g} / \mathrm{mL}$, followed by the peel extracts of rambutan (Nephelium lappaceum L.) and mangosteen (Garcinia mangostana L.), having IC $_{50}$ values of 6 and $23 \mu \mathrm{g} / \mathrm{mL}$, respectively.

To confirm the antioxidant potential of EESR and EESe, we used the ABTS method. The $\mathrm{IC}_{50}$ values for ascorbic acid, EESR, and EESe were calculated as described for the DPPH method. The results for the inhibition of the cation radicals of ABTS also demonstrated statistically equal $(p<.05) \mathrm{IC}_{50}$ values for EESR and EESe $(13.6$ and $12.0 \mu \mathrm{g} / \mathrm{mL}$, respectively) but a lower value for ascorbic acid $(2.0 \mu \mathrm{g} / \mathrm{mL})$.

Chiari et al. (2012) evaluated the antioxidant activity using the ABTS method for a $70 \%$ ethanol extract of Psidium guajava L. leaves. The $\mathrm{IC}_{50}$ was determined to be $114.4 \mu \mathrm{g} / \mathrm{mL}$, approximately 8.4 times greater than that found for EESR and 9.4 times higher than that obtained in EESe. Thus, the EESR and EESe extracts have greater antioxidant potential compared to other important antioxidant plant sources.

The suppressive effect on peroxyl radicals (AAPH/pyranine method) was also assessed for EESR. This method is based on the reduction in the pyranine fluorescence absorption when it is oxidized by peroxyl radicals (ROO*) (Campos et al., 2004). Fig. 2 shows the graphs of the kinetic profile of the fluorescence decay of pyranine with Trolox (Fig. 2a) and EESR (Fig. 2b). The difference between the graph area integrals of the 
(a)

\section{HepG2}

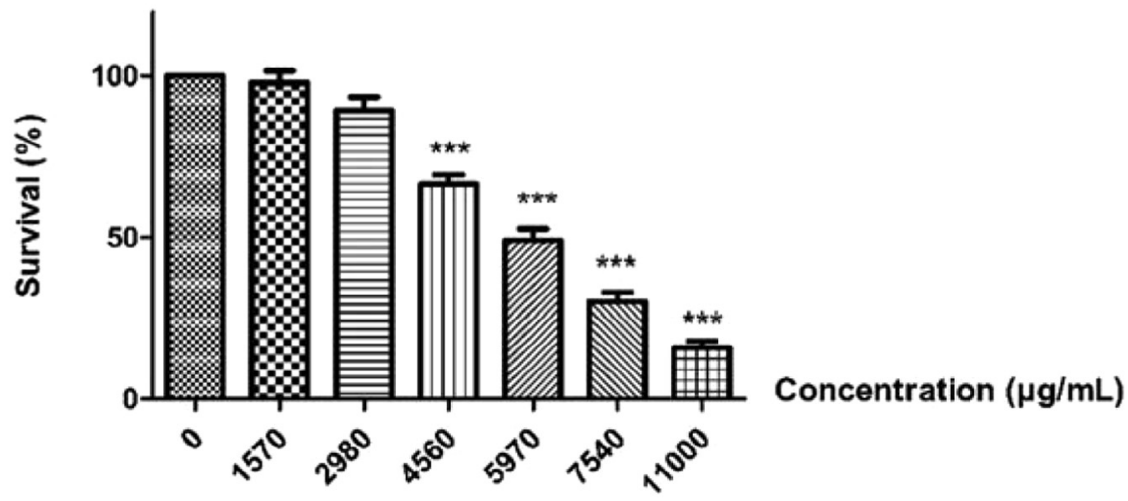

(b)

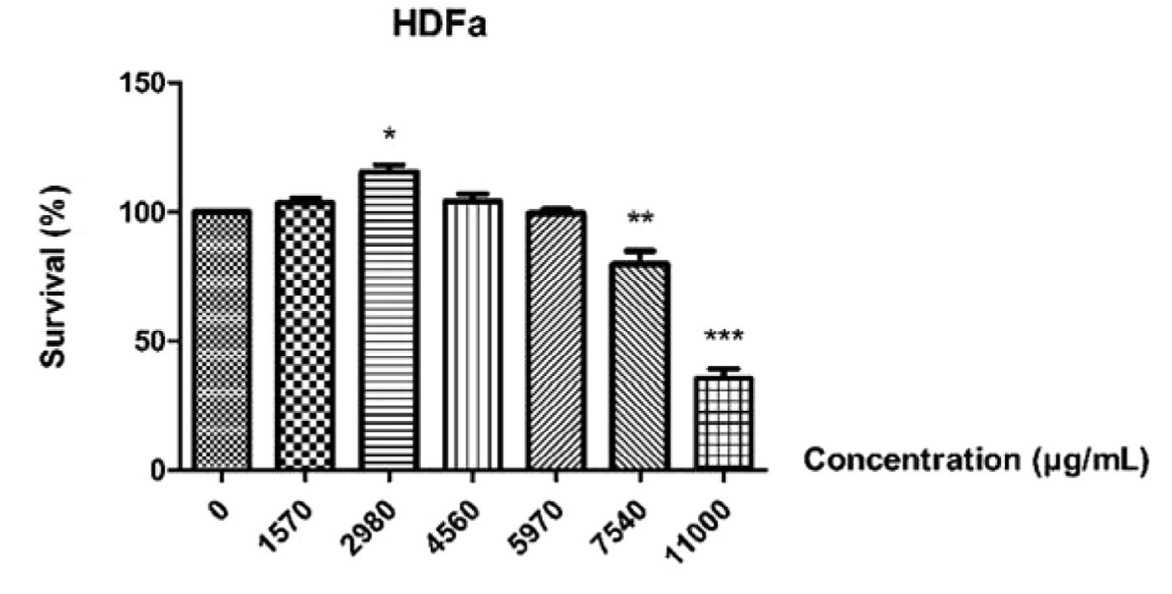

(c)

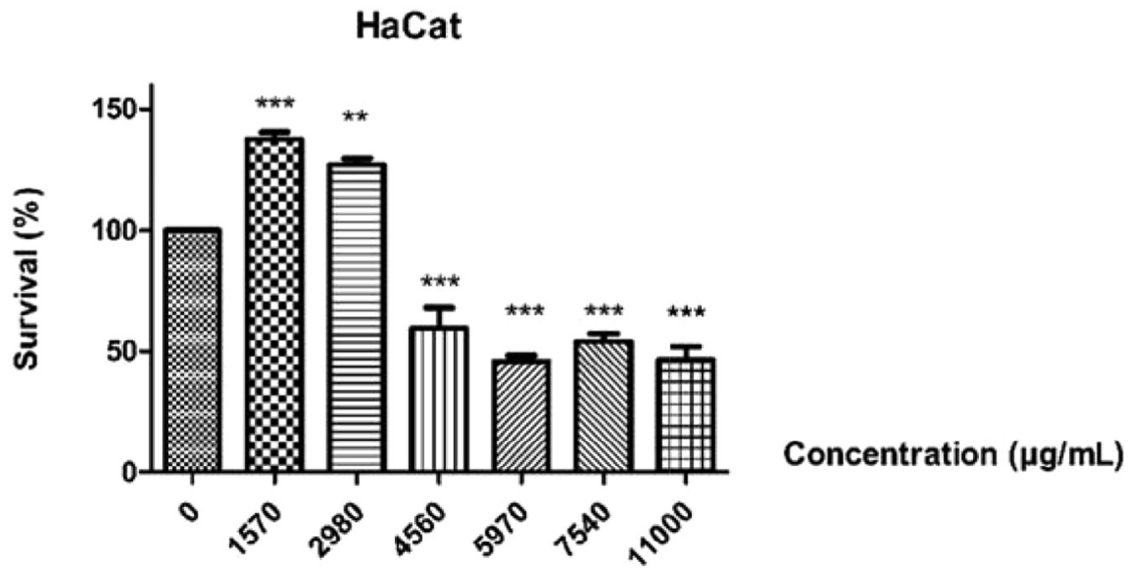

Fig. 3. Cell viability (in percentage) in HepG2 lineage (a), HDFa lineage (b), HaCat lineage (c), from the average of independent experiments (mean \pm standard deviation). Treatment performed with C. arabica EESR. Analysis of variance One-way ANOVA with Tukey's post-test. (***) $\mathrm{p}<.001 ;\left(^{* *}\right) \mathrm{p}<.01 ;\left(^{*}\right) \mathrm{p}<.05$. EESR - green seed residue extract. control and each concentration of Trolox and EESR were calculated, and linear regressions and the linear coefficients of the line (slope) were obtained. The linear coefficient of EESR was then divided by the linear coefficient of Trolox. The results of this test are expressed as TEAC units, that is, the antioxidant activity equivalent to Trolox. According to this method, the EESR had a TEAC of 1.63, indicating a higher 
antioxidant activity for peroxyl radicals than Trolox.

The results of these antioxidant assays show that the extracts have similar antioxidant activities to other plant extracts, and, thus, green seed residue is an interesting source of antioxidant compounds, which is mainly attributed to the presence of phenolic compounds. Among the main phenolic compounds, chlorogenic acids are found in higher quantities in green coffee seeds. Thus, they may be responsible for the antioxidant activity of the extracts (EESR and EESe) (Abrahão et al., 2010).

Ohnishi et al. (1994) concluded that 5-CQA, 3,5-dicaffeoylquinic acid, and caffeic acid showed higher antioxidant activity than ascorbic acid using the DPPH method, and concluded that 3,5-dicaffeoylquinic acid had higher peroxyl radical inhibiting action than chlorogenic and ascorbic acids. Rivelli et al. (2007) quantified the 5-CQA and caffeine present in aqueous and hydroethanolic extracts of Ilex paraguariensis A. St.-Hill. and tested the antioxidant activity of the extracts (DPPH method). They evaluated the possible relationship between caffeine and 5-CQA with this activity. At the concentrations tested, caffeine did not show antioxidant activity, and 5-CQA had an $\mathrm{IC}_{50}$ of $4.6 \mu \mathrm{g} / \mathrm{mL}$. Both 3,5-dicaffeoylquinic acid and 5-CQA were identified in EESR, and 5CQA was the main compound present.

\subsection{MTT assay}

The cytotoxic potential of EESR was evaluated using three cell lines, HepG2 (hepatocellular carcinoma), HaCat (keratinocytes), and HDFa (fibroblasts). The first is a human hepatoma cell line, selected in this work because it is a model widely used for studies of metabolizing cells, allowing the evaluation of the toxicity of the metabolites formed from the products under study (Chiari et al., 2012). The keratinocytes and fibroblasts were chosen because the extract has potential applications as topical skin lotion in both cosmetic or pharmaceutical products.

The cytotoxicity promoted by EESR for HepG2 cells is shown in Fig. 3a. The obtained results demonstrated that only the EESR concentrations of $4560 \mu \mathrm{g} / \mathrm{mL}$ or higher were cytotoxic for this cell line. The percentage cell survival values for these concentrations were statistically different from the control $(p<.001)$.

For the HDFa cell line (Fig. 3b), the cytotoxicity was observed for the concentrations of 7540 and $11,000 \mu \mathrm{g} / \mathrm{mL}$, having levels of significance of $p<.01$ and $p<.001$, respectively. We verified an increase in cell viability after treatment with EESR at a concentration of $2980 \mu \mathrm{g} / \mathrm{mL}(p<.05)$ and this may be related to the presence of nutrients in the extract as carbohydrates and amino acids.

Based on the dose-response profile for the HaCat (Fig. 3c), concentrations of $4560 \mu \mathrm{g} / \mathrm{mL}$ or higher led to a reduction in the percentage of cell survival with a level of significance of $p<.001$. As discussed for HDFa, the concentrations of 1570 and $2980 \mu \mathrm{g} / \mathrm{mL}$ resulted in an increase in cell viability ( $p<.001$ and $p<.01$, respectively).

The IC $_{50}$ values for HepG2, HaCat, and fibroblasts were $6952.6 \pm 673.8,6007.4 \pm 544.8$, and $9883.2 \pm 65.3 \mu \mathrm{g} / \mathrm{mL}$, respectively. These concentrations, able to reduce the viability of these cells lines by $50 \%$, can be considered very high in relation to the concentrations necessary for this extract to exhibit biological activity, demonstrating the safety of EESR. This margin of safety (in this case, the toxic concentration divided by the effective concentration) is good because these concentrations are thousands of times higher than the concentrations obtained, for example, to scavenge $50 \%$ of the free radicals determined in the antioxidant determination assays. This safety based on cytotoxicity tests can be inferred by comparing the results obtained in the study of Martínez et al. (1999), who tested the cytotoxic potential of fruits and vegetables. The concentration of the plant extracts was $5000 \mu \mathrm{g} / \mathrm{mL}$, resulting in approximately $80 \%$ cell death. This concentration is considered high, and the cytotoxic potential of these products is, thus, considered insignificant by the authors. EESR safety should also be considered taking into account the use of coffee as a beverage and in food and cosmetic products.

\section{Conclusions}

The antioxidant activities of green coffee seed residue extract and green coffee seed extract are similar and significant in comparison to other coffee by-products. According to the quantitative chemical analyses using UPLC-UV, we concluded that 5-CQA is the main compound in EESR, suggesting that it makes a large contribution to the antioxidant activity of its extract, as already established in the literature. The contents of both 5-CQA and caffeine were similar in the EESe and EESR. In the UPLC-ESI-QTOF-MS ${ }^{\mathrm{E}}$ analysis, five monoacyl and three diacyl esters of trans-cinnamic acids and quinic acid were identified: 3-caffeoylquinic, 4-caffeoylquinic and 5-caffeoylquinic acids, 5-p-coumaroylquinic acid, 5-feruloylquinic acid, 3,4- dicaffeoylquinic acid, 3,5dicaffeoylquinic acid, and 4,5- dicaffeoylquinic acid. A comparison of the chemical composition of EESR and EESe indicates that green coffee seed residue is an interesting source of caffeine and esters of transcinnamic acids and quinic acid as chlorogenic acids. In addition, EESR may be considered safe at the concentrations employed according to the cytotoxicity assay using the MTT method. Thus, $C$. arabica green seed residue extract (EESR) presents great potential to be used as raw material for dietary supplements, cosmetic and pharmaceutical products or as a source of bioactive antioxidant compounds, and this by-product utilization is consistent with green chemistry goals, having environmental and economic benefits.

\section{Acknowledgments}

We thank the coffee cooperative Cooxupé (Guaxupé, Minas Gerais, Brazil) for donating the green seed residue and the green seeds of $C$. arabica L. In addition, we thank the Scientific Support and Development Program of the School of Pharmaceutical Sciences (UNESP), FAPESP, CNPq for financial support.

\section{Appendix A. Supplementary data}

Supplementary data associated with this article can be found, in the online version, at http://dx.doi.org/10.1016/j.foodchem.2017.10.153.

\section{References}

Abrahão, S. A., Pereira, R. G. F. A., Duarte, S. M. S., Lima, A. R., Alvarenga, D. J., \& Ferreira, E. B. (2010). Compostos bioativos e atividade antioxidante do café (Coffea arabica L.). Ciência e Agrotecnologia, 34, 414-420.

Abrahão, S. A., Pereira, R. G. F. A., Lima, A. R., Ferreira, E. B. \& Malta, M. R. (2008). Compostos bioativos em café integral e descafeinado e qualidade sensorial da bebida. Pesquisa Agropecuária Brasileira, 43, 1799-1804.

Aulton, M. E. (2005). Delineamento de Formas Farmacêuticas ((2 $2^{\mathrm{a}}$ ed.)). Artmed.

Brasil (2010). Farmacopeia brasileira (( $5^{\circ}$ ed. Vol. 1)). ANVISA/Fundação Oswaldo Cruz.

Campos, A. M., Sotomayor, C. P., Pino, E., \& Lissi, E. (2004). A pyranine based procedure for evaluation of the total antioxidant potential (TRAP) of polyphenols: A comparison with closely related methodologies. Biological Research, 37, 287-292.

Chiari, B. G., Martini, P. C., Moraes, J. D. D., Andréo, R., Corrêa, M. A., Cicarelli, R. M. B., et al. (2012). Use of HEPG2 cells to assay the safety of cosmetic active substances. International Journal of Research in Cosmetic Science, 2(2), 8-14.

Clifford, M. N., Johnston, K. L., Knight, S., \& Kuhnert, N. (2003). Hierarchical scheme for LC-MSn identification of chlorogenic acids. Journal of Agricultural and Food Chemistry, 51(10), 2900-2911.

Clifford, M. N., Knight, S., \& Kuhnert, N. (2005). Discriminating between the six isomers of dicaffeoylquinic acid by LC-MS(n). Journal of Agricultural and Food Chemistry, 53(10), 3821-3832.

Dudonné, S., Vitrac, X., Coutière, P., Woillez, M., \& Mérillon, J.-M. (2009). Comparative study of antioxidant properties and total phenolic content of 30 plant extracts of industrial interest using DPPH, ABTS, FRAP, SOD, and ORAC assays. Journal of Agricultural and Food Chemistry, 57(5), 1768-1774.

Farias, L. A., \& Fávaro, D. I. T. (2011). Vinte anos de química verde: Conquistas e desafios. Química Nova, 34, 1089-1093.

Jeszka-Skowron, M., Sentkowska, A., Pyrzyńska, K., \& De Pena, M. P. (2016). Chlorogenic acids, caffeine content and antioxidant properties of green coffee extracts: Influence of green coffee bean preparation. European Food Research and Technology, 242, 1403-1409.

Jeszka-Skowron, M., Stanisz, E., \& De Pena, M. P. (2016). Relationship between antioxidant capacity, chlorogenic acids and elemental composition of green coffee. $L W T$ Food Science and Technology, 73, 243-250. 
Martínez, A., Ikken, Y., Cambero, M. I., Marín, M. L., Haza, A. I., Casas, C., et al. (1999). Mutagenicity and cytotoxicity of fruits and vegetables evaluated by the Ames test and 3-(4,5-dimethylthiazol-2-yl)- 2,5-diphenyltetrazolium bromide (MTT) assay/ Mutagenicidad y citotoxicidad de frutas y vegetales evaluadas por el test de Ames y el ensayo del bromuro de 3-(4,5-dimetiltiazol-2-il)-2,5-difeniltetrazolio (MTT). Food Science and Technology International, 5(5), 431-437.

Mensor, L. L., Menezes, F. S., Leitao, G. G., Reis, A. S., dos Santos, T. C., Coube, C. S., et al. (2001). Screening of Brazilian plant extracts for antioxidant activity by the use of DPPH free radical method. Phytotherapy Research, 15(2), 127-130.

Monteiro, M. C., \& Trugo, L. C. (2005). Determinação de compostos bioativos em amostras comerciais de café torrado. Química Nova, 28, 637-641.

Mosmann, T. (1983). Rapid colorimetric assay for cellular growth and survival: Application to proliferation and cytotoxicity assays. Journal of Immunological Methods, 65(1-2), 55-63.

Müller, L., Fröhlich, K., \& Böhm, V. (2011). Comparative antioxidant activities of carotenoids measured by ferric reducing antioxidant power (FRAP), ABTS bleaching assay ( $\alpha$ TEAC), DPPH assay and peroxyl radical scavenging assay. Food Chemistry, 129(1), 139-148.

Murthy, P. S., \& Naidu, M. M. (2012). Recovery of phenolic antioxidants and functional compounds from coffee industry by-products. Food and Bioprocess Technology, 5(3), 897-903.

Naczk, M., \& Shahidi, F. (2004). Extraction and analysis of phenolics in food. Journal of Chromatography A, 1054(1-2), 95-111.

Narita, Y., \& Inouye, K. (2012). High antioxidant activity of coffee silverskin extracts obtained by the treatment of coffee silverskin with subcritical water. Food Chemistry, 135(3), 943-949.

Ohnishi, M., Morishita, H., Iwahashi, H., Toda, S., Shirataki, Y., Kimura, M., et al. (1994). Inhibitory effects of chlorogenic acids on linoleic acid peroxidation and haemolysis. Phytochemistry, 36(3), 579-583.

Okonogi, S., Duangrat, C., Anuchpreeda, S., Tachakittirungrod, S., \& Chowwanapoonpohn, S. (2007). Comparison of antioxidant capacities and cytotoxicities of certain fruit peels. Food Chemistry, 103(3), 839-846.

Parras, P., Martínez-Tomé, M., Jiménez, A. M., \& Murcia, M. A. (2007). Antioxidant capacity of coffees of several origins brewed following three different procedures. Food Chemistry, 102(3), 582-592.

Peschel, W., Sánchez-Rabaneda, F., Diekmann, W., Plescher, A., Gartzía, I., Jiménez, D., et al. (2006). An industrial approach in the search of natural antioxidants from vegetable and fruit wastes. Food Chemistry, 97(1), 137-150.

Prado, A. G. S. (2003). Química verde, os desafios da química do novo milênio. Química Nova, 26, 738-744.

Rivelli, D. P., Ropke, C. D., Silva, V. V., Miranda, D. V., Almeida, R. L., Sawada, T. C. H., et al. (2007). Simultaneous determination of chlorogenic acid, caffeic acid and caffeine in hydroalcoholic and aqueous extracts of Ilex paraguariensis by HPLC and correlation with antioxidant capacity of the extracts by DPPH reduction. Revista Brasileira de Ciências Farmacêuticas, 43(2), 215-222.

Rodrigues, S., Calhelha, R. C., Barreira, J. C. M., Dueñas, M., Carvalho, A. M., Abreu, R. M. V., et al. (2012). Crataegus monogyna buds and fruits phenolic extracts: Growth inhibitory activity on human tumor cell lines and chemical characterization by HPLC-DAD-ESI/MS. Food Research International, 49(1), 516-523.

Rufino, M. S. M., Alves, R. E., Brito, E. S., De Morais, S. M., Sampaio, C. G., Pérez-Jiménez, J., et al. (2007). Metodologia Científica: Determinação da Atividade Antioxidante Total em Frutas pela Captura do Radical Livre ABTS. Comunicado Técnico on line (EMBRAPA)(128).

Russo, D., Kenny, O., Smyth, T. D., Milella, L., Hossain, M. B., Diop, M. S., et al. (2013) Profiling of phytochemicals in tissues from Sclerocarya birrea by HPLC-MS and their link with antioxidant activity. ISRN Chromatography, 2013(1), 1-11.

Sant'Anna, V., Biondo, E., Kolchinski, E. M., da Silva, L. F. S., Corrêa, A. P. F., Bach, E., et al. (2017). Total polyphenols, antioxidant, antimicrobial and allelopathic activities of spend coffee ground aqueous extract. Waste and Biomass Valorization, 8(2), 439-442.

Schieber, A., Keller, P., \& Carle, R. (2001). Determination of phenolic acids and flavonoids of apple and pear by high-performance liquid chromatography. Journal of Chromatography A, 910(2), 265-273.

Shouqin, Z., Jun, X., \& Changzheng, W. (2005). High hydrostatic pressure extraction of flavonoids from propolis. Journal of Chemical Technology \& Biotechnology, 80(1), 50-54.

Singleton, V. L., Orthofer, R., \& Lamuela-Raventós, R. M. (1999). Analysis of total phenols and other oxidation substrates and antioxidants by means of folin-ciocalteu reagent. Methods in Enzymology (pp. 152-178). Academic Press.

Sousa, J. N., Pedroso, N. B., Borges, L. L., Oliveira, G. A., Paula, J. R., \& Conceição, E. C. (2014). Optimization of Ultrasound-assisted extraction of polyphenols, tannins and epigallocatechin gallate from barks of Stryphnodendron adstringens (Mart.) Coville bark extracts. Pharmacognosy Magazine, 10(Suppl. 2), S318-S323.

Speer, K., \& Kölling-Speer (2001). Lipids. Coffee recent developments (pp. 33-49). Oxford: Blackwell Science.

Vallverdu-Queralt, A., Jauregui, O., Medina-Remon, A., Andres-Lacueva, C., \& LamuelaRaventos, R. M. (2010). Improved characterization of tomato polyphenols using liquid chromatography/electrospray ionization linear ion trap quadrupole Orbitrap mass spectrometry and liquid chromatography/electrospray ionization tandem mass spectrometry. Rapid Communications in Mass Spectrometry, 24(20), 2986-2992.

VelazquezPeredaMdel, C., DieamantGde, C., Eberlin, S., Nogueira, C., Colombi, D., Di Stasi, L. C., et al. (2009). Effect of green Coffea arabica L. seed oil on extracellular matrix components and water-channel expression in in vitro and ex vivo human skin models. Journal of Cosmetic Dermatology, 8(1), 56-62.

Yuan, L., Zhang, Z., Hou, Z., Yang, B., Li, A., Guo, X., et al. (2015). Rapid classification and identification of complex chemical compositions in traditional Chinese medicine based on UPLC-Q-TOF/MS coupled with data processing techniques using the KuDieZi injection as an example. Analytical Methods, 5210-5217.

Zhang, Y., Wu, L. J., Tashiro, S., Onodera, S., \& Ikejima, T. (2004). Evodiamine induces tumor cell death through different pathways: Apoptosis and necrosis. Acta Pharmacologica Sinica, 25(1), 83-89.

Zuorro, A., \& Lavecchia, R. (2012). Spent coffee grounds as a valuable source of phenolic compounds and bioenergy. Journal of Cleaner Production, 34, 49-56. 